\title{
"I am rather strong on Voyages and Cannibalism": The other Dickens and other Victorians in Richard Flanagan's Wanting
}

\section{Bożena Kucała}

Jagiellonian University in Kraków, Poland

This paper analyses Richard Flanagan's novel Wanting (2008) as a narrative informed by a revisionary and critical attitude to nineteenth-century ideologies, which is common to, and, indeed, stereotypical in much neo-Victorian fiction. Drawing on the biographies of two eminent Victorians: Charles Dickens and Sir Fohn Franklin, Flanagan constructs their fictional counterparts as split between a respectable, public persona and a dark, inner self. While all the Victorian characters are represented as "other" than their public image, the focus in the novel, and in this paper, is on Dickens's struggle to reconcile social propriety with his personal discontent. Flanagan represents this conflict through Dickens's response to the allegations that starving survivors of Franklin's ill-fated Arctic expedition resorted to cannibalism. The zeal with which the Victorian writer refuted such reports reveals his own difficulty in living up to social and moral norms. The paper argues that the main link between the different narrative strands in the novel is the challenge they collectively pose to the distinction between the notions of civilization and savagery.

\section{Keywords}

Charles Dickens; Richard Flanagan; neo-Victorian fiction; postcolonial literature; Australian literature; historical fiction; biofiction

The Victorian scholar Simon Joyce contends that there is "a popular consensus" about the Victorian era. The simplified, stereotypical definition of the period is reducible to a predictable formula: it was an age of "a confidently triumphalist imperialism, a rigid separation of public and private spheres, a repressive sexual morality, and an ascendant hegemony of middle class values" (4). Some seminal postwar works on Victorianism helped to consolidate and reinforce this image. Steven Marcus's book The Other Victorians: A Study of Pornography 
and Sexuality in Mid-Nineteenth-Century England (1966), by exploring socially tabooed areas of Victorian life, confirmed the common perception of the era as polarized between outward respectability and propriety on the one hand, and a concealed life of excess and transgression on the other; Marcus represents the Victorian official culture and the subculture as "mirror images, negative analogues of each other" (qtd. in Joyce 5). Marcus's book had the effect of emphasizing the marginalized and the repressed in modern critical reassessments of Victorianism. Challenging Marcus's portrayal of the nineteenth century, Michel Foucault in "We 'Other Victorians"” (History of Sexuality) claimed that the "repressive hypothesis" was far-fetched and reductive in its binarism (cf. Joyce 5,16 ). Nevertheless, both works drew attention to studies of sexuality as one of the chief modern vantage points from which to re-read the Victorians. As John McGowan claims, "[n]o restaging of Victorian life is complete without reassuring us that we are more enlightened sexually than those repressed Victorians" (11).

Other defining aspects of the "popular consensus" about Victorianism easily lend themselves to exploration from contemporary perspectives: nineteenthcentury imperialism, race relations, "the woman question", matters of class identity and class relations feature prominently both in scholarship as well as contemporary fictional portrayals of the era. The emergence of neo-Victorian fiction may be said to correspond to developments in critical approaches, "from feminism to structuralism to post-structuralism, to postcolonialism, to queer studies" (Humpherys 446). A major tendency in neo-Victorian novels is the revising and challenging of Victorian ideas by re-writing canonical narratives with a view to exposing omissions, deficiencies or ideologically flawed representations; indeed, many contemporary novels about the Victorians are mediated through widespread popular assumptions about the nineteenth century. In their Introduction to Neo-Victorianism: The Victorians in the Trenty-First Century, 1999-2009, Ann Heilmann and Mark Llewellyn note that some historical novels set in the nineteenth century tend to descend into a catalogue of clichés (6). The American scholar Miriam Elizabeth Burstein satirized this genre by providing potential writers with an eleven-rule formula for producing a successful contemporary novel with a Victorian setting. The general principle is to address received ideas about how repressed, hypocritical and unfair Victorian society was. For the purposes of the present paper, it is useful to quote rule 5: "Any outwardly respectable man will a) have frequent recourse to Prostitutes, b) have a Dark Secret, and/or c) be Jack the Ripper". 
And, finally, rule 11 says that the book should be publicized by "using the adjective 'Dickensian' at least once" (qtd. in Heilmann and Llewellyn 7).

Richard Flanagan's neo-Victorian novel Wanting (2008) ${ }^{1}$, which engages with the life of Charles Dickens and his contemporaries, is underpinned by the stereotypical idea of Victorian repression and a split between the public and the private self. The Victorian men and the Victorian woman depicted in the novel all have their dark secrets while the widespread controversy concerning Sir John Franklin's lost expedition, as represented in the book, suggests that their anxieties and fears about inner darkness are in fact a matter of a shared condition. Flanagan emulates the mode of writing about well-known Victorians as "others" in relation to their established public selves. The equivocality of "wanting" in the title is conveyed by the two quotations chosen as epigraphs: the one from Dostoevsky associates "wanting" with desire which is beyond reason, while the lines from Ecclesiastes consider "wanting" as that which is missing. However, while exposing Victorian hypocrisy, class snobbery, racial prejudice and sexual repression, the writer eschews a conclusive identification of what is "wanting" in his characters' lives. Instead, Dickens and the other Victorians are shown as driven by conflicting motives and impulses, often confused about their objectives, struggling and failing to achieve a balance between social respectability and personal fulfilment. As a result, they appear misguided and lost rather than intentionally hypocritical. What Dickens, Sir John Franklin, his wife Lady Franklin and George Augustus Robinson ${ }^{2}$ have in common is a vague sense of dissatisfaction with life, and a conviction that what could make their lives worthwhile is beyond their reach. Nevertheless, as literary characters, they come across as rather two-dimensional in the sense of having a well-defined public self and, in opposition to it, an inner, submerged self, obscure and dark, which chafes at the norms that the person is obliged to obey. This paper aims to demonstrate how the novel consistently represents the Victorians, especially Charles Dickens, as other than their public selves. It will be argued that the common denominator for a critique of both Victorian mores and Victorian imperialism in Wanting is the problematic distinction between the notions of civilization and savagery.

Wanting is largely a dramatization of episodes from the lives of a few eminent Victorians. Charles Dickens is captured in the 1850 os, during his years of personal crisis when his marriage was falling apart, domestic life had become a burden, and his immense popularity and public reputation clashed with private discontent, restlessness and frustration. In his biography of Dickens, 
John Forster states that "an unsettled feeling" became at that time "almost habitual" with him (193). Dickens's growing estrangement from his wife, which led to mutual bitterness and ended in official separation, also caused the writer much distress because it was difficult for a man of his stature to keep details of his private problems concealed from the public. What Dickens called, in a letter quoted by Forster, "the skeleton in my domestic closet [...] becoming a pretty big one" (198) has been fleshed out in modern biographies by Peter Ackroyd (1990), Claire Tomalin (2001) and Jane Smiley (2002). An even bigger skeleton was Dickens's intimate friendship with a young actress, Ellen Ternan. Forster makes no mention of her at all, besides appending a copy of Dickens's last will, in which she is named. By contrast, Tomalin forcefully argues that they had an affair, which very likely resulted in the birth of an illegitimate child (326-333). Due to a scarcity of evidence, Smiley is unwilling to take biographical speculation this far, and restricts herself to acknowledging the secrecy that surrounds this part of the writer's biography, as well as commenting that whereas previously Dickens had tried to meet his own and his society's norms, after meeting Ellen he began to live two lives: "The man who had as large a role as anyone in creating 'Victorian Englishness', that domestic ideal of comfort, coziness, business, and celebration, henceforth lived his life in direct contradiction to that very ideal" (154). ${ }^{3}$

A different narrative strand in Flanagan's novel revolves around the life of Sir John Franklin, a navy officer and an Arctic explorer. ${ }^{4}$ However, although the novel's temporal span extends beyond the debacle of Franklin's last expedition, it recreates mainly the Tasmanian period of his life. ${ }^{5}$ This part of Flanagan's novel has a distinctly revisionist, postcolonial bent. But, as Giles Foden observes in his review of the novel, Wanting aligns itself with the current tendency in postcolonial fiction which, rather than placing the imperial centre and the colonized territories in opposition, aims to show them as "inextricably linked", creating "a constant duplex or indeed multiplex effect, the literary equivalent of globalisation" (Foden). Although Wanting is "a bleak counternarrative ... to conventional British colonial narratives" (Bridgham 161), it also emphasizes connections between public history and the private lives of the Victorians - living up to the ideals of civilized behaviour is challenging in both spheres, and the ideals themselves are subject to questioning. Accordingly, the novel intimates that both Franklin's erratic, inconsistent actions as governor of Van Diemen's Land (as Tasmania was called before 1856) and his determination to go on another expedition originated in his personal failures, and his sense of "wanting". 
By the writer's own admission, the inspiration for the novel came from a painting he saw in a museum in Hobart. It was Thomas Bock's portrait of Mathinna, an aboriginal girl adopted by Franklin and his wife while he was governor of the island. The incompatibility of the girl's European-style dress and her bare feet (although concealed by the frame of the painting) illustrates her status as a native whom the English tried to civilize (cf. Charles; Raabus). Not much is known about the fate of Mathinna, except that she did not follow the Franklins to Europe and died a few years after their departure, apparently having taken to drink. A tragic story appears to inhere behind those few facts, and Flanagan fully develops those implications by constructing a tale of child abuse (comparable with Dickens's portrayals) coupled with victimization through imperialist cultural arrogance. The novel recounts how her life was doubly damaged by the supposedly superior culture: she was sexually abused by Franklin (although it must be said that there is no such implication in historical sources [Kakutani]); furthermore, cultural hybridization made the girl unfit to live either among the English or her own people.

The life of John Franklin, which is ultimately overshadowed in the novel by the imaginary narrative of the aboriginal girl, seems very remote from Dickens's domestic turmoil. And yet, in real life as well as in Flanagan's novel, their stories did cross at a certain point - although posthumously on the part of Franklin. In 1845, Franklin led his second expedition to the Arctic, in search of the Northwest Passage. Nothing was known about the mysterious disappearance of the expedition until 1854, when the Scottish explorer John Rae encountered Inuit who possessed artefacts from the ships and claimed to have seen remains of white men. Their accounts also suggested that the starving explorers had resorted to cannibalism, or, as the explorer euphemistically put it in his report, "had been driven to the last dread alternative as a means of sustaining life" (Rae 301). Rae immediately relayed the news to the Admiralty (Dalton 118-120). Further evidence which began to emerge left no doubt as to the tragic loss of the entire expedition, but it was Rae's revelations regarding cannibalism that "shook Victorian England to its foundations" (McCoogan 2). ${ }^{6}$ As part of her vigorous campaign to repudiate Rae's report and salvage her husband's reputation, Franklin's widow successfully enlisted the help of England's most popular novelist, who soon obliged by writing a two-part essay "The Lost Arctic Voyagers". After a conversation with Lady Jane, Dickens wrote to his sub-editor: "It has occurred to me that I am rather strong on Voyages and Cannibalism 7 , and might do an interesting little paper for next No. on that part of Dr Rae's report; taking the arguments 
against its probabilities" (qtd. in Slater, Dickens fournals Online). The essay appeared in two parts, on $2^{\text {nd }}$ and $9^{\text {th }}$ December 1854 , in issues of Dickens's own weekly journal Household Words. The writer also published Rae's response, which restated the explorer's claims, as well as a copy of the original report (McCoogan 6).

Dickens's rebuttal of Rae's assertions is grounded in the presumed existence of an unbridgeable divide between a civilized man and a savage. Drawing on accounts of previous expeditions, he praises Franklin himself and the heroism of English explorers while casting doubt on the reliability of the Esquimaux [Inuit] account: "We submit [...] that the noble conduct and example of such men, and of their own great leader himself, under similar endurances, belies it, and outweighs by the weight of the whole universe the chatter of a gross handful of uncivilised people, with domesticity of blood and blubber" (Dickens, "The Lost Arctic Voyagers" [part II] 392). In "possibly the strangest and most intemperate piece of journalism he ever wrote" (Boyd 2009), Dickens opines that "every savage [is] in his heart covetous, treacherous, and cruel", given to lies, boasting as well as figurative talk ("The Lost Arctic Voyagers" [part I] 362). The writer eventually suggests that it is not inconceivable that the Esquimaux themselves attacked and devoured the white men. ${ }^{8}$ In the words of Ackroyd, "[i]t is so strange an article, in fact, that it throws more light on his own excitable and anxious state of mind than upon the ostensible subject of his concern" (712-713).

This intersection between the lives of Charles Dickens and John Franklin may appear tenuous, accidental and dismissible; Dickens's biographers devote to it no more than a few paragraphs, focusing instead on the beginning of the writer's acquaintance with Ellen Ternan, who was one of the actresses he hired for the play The Frozen Deep, written by Wilkie Collins in defiance of Rae's report. Yet, in Flanagan's novel, Dickens's reaction to the potential defamation of the famous explorer is represented as very personally motivated, and symptomatic of the jarring duality in the writer's own life. As one reviewer put it, the former is "a man starving for love", the latter - "a man just plain starving" (Grossman 6o).

Flanagan follows closely Dickens's biography, incorporating near-verbatim quotations from his writings, which include the essay on the lost expedition (e.g., 25, 31, 38). Without attempting to imitate nineteenth-century English, Flanagan nevertheless remains faithful to the Victorian type of novel by introducing an omniscient, third person narrator, who regularly offers insight into the characters' minds. Although the author does not overtly display the 
contemporary perspective from which the stories are told, the retrospective dimension of the novel is hinted at in those passages in which the narrator, taking a broader view, points out historical developments taking place simultaneously in different parts of the world 9 , defines the values professed by middle class British society at that moment in history ${ }^{10}$, or uses prolepsis. ${ }^{11}$ On the thematic level, Flanagan's modern-day critical engagement with Victorian ideologies consists in his narrator's recounting of nineteenth-century views and beliefs that are blatantly at odds with modern approaches and sensibilities. For instance, the clichés about English imperialism are summed up in the outline of George Augustus Robinson's career as an officer in Van Diemen's Land: "the preacher took on the official title of Protector and a salary of $£_{5} \mathrm{OO}$ a year, along with a small garrison of soldiers and a Catechist, and set about raising his sable charges ${ }^{12}$ to the level of English civilisation" (2). The narrative proceeds to register the Protector's bewilderment at the fact that his well-intentioned actions have disastrous results, as the aboriginal population, when forced to adjust to English ways, starts to die at an alarming rate. The internal anachronies and the interweaving of narrative strands in the book serve to expose discrepancies between Victorian ideologies and imperialist as well as domestic practices.

The postcolonial part of the book demonstrates the dubiousness of the civilizational standards which the representatives of the Empire were trying to impose on others. There is a striking irony in the fact that the Protector's civilizing mission entails carrying out amateurish autopsies on the bodies of the aboriginals, in the interest of science. His efforts at championing civilization include gory experiments - he has no qualms about cutting off the head of King Romeo, an aboriginal tribal chief (19-20), and subsequently flensing, boiling it and exhibiting the skull as a prized possession (69). The reader obviously cannot miss the supreme irony inherent in the contrast between Lady Jane's later outrage and disgust at the allegations of cannibalism, and, on the other hand, her delight at the gift of the skull during her stay in Tasmania (68). $\cdot^{13}$ Her conversation with Charles Dickens following the publication of Rae's report (which is narrated prior to the account of her Tasmanian stay) centres on the presumably wide gulf between civilization and savagery but the Tasmanian skull she produces as scientific "proof" of that distinction immediately proves the exact opposite in the context of the novel: that the boundary between the two concepts is very fluid, as they are in fact dangerously close and in need of redefinition.

The Victorian anthropologist Edward Burnett Tylor defined this opposition 
in terms of "the absence or presence, high or low development" of industry, agriculture, architecture and scientific knowledge, which may be summed up as the ability to adapt nature to human needs. Tylor's criteria, however, include also aspects of social and moral life: "the condition of religious belief and ceremony", "the degree of social and political organization" as well as "the definiteness of moral principles" (26-27). Tylor insists on the inseparability of intelligence and moral standards as the prerequisite for advancing civilization. His seminal publication Primitive Culture (1871) initiated the emergence of a Darwinian, evolutionary phase of cultural anthropology (Brantlinger 5455). Tylor expresses a widespread Victorian belief when he expounds on the evolutionary view of mankind's history, of which savagery and sophisticated civilized life, the latter represented by the current "educated world of Europe and America", are the origin and the end, respectively (26-27). Progress, although inevitable, proceeds at different paces in different parts of the world and so at a given stage in history civilization exists "in different grades" (26). Tylor argues that, drawing on the criteria enumerated above, it is possible to set up a hierarchy of races - he himself places the aboriginal Australians at the lowest level (27) $\cdot^{14}$ This evolutionary view is complicated by the rival theory of degeneration; Tylor acknowledges that advance is occasionally counterbalanced by relapse, nevertheless arguing that the principle of development prevails $\left(3^{8}\right)$. Although under certain conditions civilized men may degenerate into a state resembling savagery (of which the "miserable" and "depraved" "dangerous classes" in British cities may be an example [42]), a savage community is never actually reproduced (43).

Whereas one of the questions underlying the Empire's civilizing mission was whether the natives in colonized territories could become fully civilized, the reverse anxiety was over white men "going native" (Brantlinger $65-66$ ). The nineteenth-century history of Tasmania provided at least one such example. In the early 1800 , eight transported convicts escaped from Macquarie Harbour and, finding it difficult to survive, they subsequently killed and ate one another. The sole survivor, an Irishman named Alexander Pearce, was recaptured while in possession of a chunk of human flesh (Brantlinger 66). ${ }^{15}$ Dickens's Great Expectations features a near-savage in the midst of a civilized community, a member of what Tylor calls "the dangerous classes". Catching Pip at the cemetery, Magwitch threatens to tear out, roast and eat his heart and liver (Dickens, Great Expectations 38). Brantlinger points out that to Dickens and his contemporaries cannibalism was "the nadir of savagery, the complete antithesis of civilization" (66). It is interesting to juxtapose the writer's earlier 
fiery defence of the polar explorers with his admission in Great Expectations of the threat of civilizational lapse.

In Wanting, the fictional Dickens's response to the report about cannibalism is not as unambiguous as it might appear from his biographies. Listening to Lady Jane's outraged refutation of Rae's report, Dickens silently reflects that Franklin "would have to eat something to maintain that enormous bulk of his" (27). The combination of dialogue with the narrator's representation of the interlocutors' thoughts exposes their real, unspoken motivation. Although they echo each other's words in condemning the savage as a deceitful, unreliable witness - which was to become Dickens's main argument in his article - each of them suppresses discomfiting memories. Lady Jane struggles with her longing for the adopted aboriginal daughter and tries to deaden her sense of guilt over what happened to the girl. Dickens, on the other hand, is haunted by his childhood trauma of the blacking factory, his low social background, his unfulfilled first love and his links to the criminal world through his father's imprisonment for debt. The writer is secretly flattered that the rich and powerful seek his help, and enjoys his own empowerment: "He, the debtor's son, was now to be their creditor" (27). Thus, the encounter between Dickens and Lady Jane takes place on two levels at once: while in the verbal exchanges their views converge as they echo and reinforce each other's strong opinions, the narratorial exposure of their thoughts reveals their doubts, anxieties, and, above all, a personal need to uphold their images as respectable, rational and civilized persons.

During the conversation they jointly define the distinction between civilization and savagery as the distance between desire and reason (30). As in Tylor's book Primitive Culture, the two concepts are construed by the Victorians in Flanagan's novel in relation to each other. However, the strict binarism Dickens and Lady Jane wish to maintain is belied, continually fractured and invalidated by the events in the novel - not only by allegations of actual cannibalism committed by civilized men, but also by instances of predatory colonial exploitation of the indigenous people of Tasmania. The reservation on Flinders Island, set up by George Augustus Robinson as part of his mission, was run on the principle that civilization means "a system of restraint and plodding methodised daily pursuits" (qtd. in Brantlinger 53-54). In his novel, Flanagan draws on historical facts to show the destructive influence which this project had on the aboriginals. If cannibalism was understood by Dickens and his contemporaries as the most obvious mark of savagery, then the conclusion of Flanagan's novel constitutes the most severe condemnation 
of the role of civilization in the history of the island. The final episode, which shows the body of Mathinna - one of the last aboriginal Tasmanians and a victim of misguided civilizing efforts - being devoured by birds, suggests that the imperialist civilization has metaphorically cannibalized her and her countrymen. ${ }^{16}$

The desire vs reason polarity is rephrased and reiterated throughout the novel, becoming its conspicuous leitmotif. Rationality, self-control, restraint, or "the capacity to conquer desire" (47) is what the Victorians value and outwardly follow; passion, instinct and the titular "wanting" is what they suppress or, conversely, occasionally yield to. The fictional Dickens reflects that "his whole life was an object lesson in control of one's passions" (30). The Victorians' tacit recognition of the tension between their desires and the need to control them in an attempt "to repress one's inner savage" (Bridgham 159) foreshadows Freud's meditations in Civilization and Its Discontents (1930). Freud thinks of civilization in terms of "a special process which mankind undergoes" (69), a progression from unrestrained satisfaction of instincts to a repression of those instincts. However, the repression which makes civilization possible generates frustration, neurosis and unhappiness in individuals. Society imposes its own rules, but individuals also develop inner mechanisms against their instinctual impulses; thus a sense of guilt, which hinders the violation of inner norms, is, according to Freud, "the price we pay for our advance in civilization" (Freud 81).

Wanting portrays Dickens as frustrated, conflicted and discontent, failing "to discipline his own great undisciplined heart" (48), as he says himself. In the midst of his busy, successful social life, he secretly agonizes over his failed marriage and past unhappiness. For her part, Lady Franklin suppresses her maternal instincts towards the aboriginal girl, thus depriving herself of emotional fulfilment and condemning the girl to body- and soul-destroying discipline and, eventually, death. There is clearly a proto-Freudian (or postFreudian, if the date of the novel's publication is taken into account) line of thought in Dickens's acknowledgement that we often "have to do violence to our feelings $[\ldots]$ so we can bravely discharge our duties and responsibilities" (7). However, despite following much neo-Victorian fiction in foregrounding repression in the representation of the Victorian era ${ }^{17}$, Flanagan's novel refuses to automatically endorse freedom from restraint as the beneficial alternative. A range of consequences may follow acts of transgression. Robinson experiences a moment of freedom and transcendental abandon, or what Freud would call an "oceanic feeling", ${ }^{18}$ when he spontaneously joins a wild aboriginal dance. 
But a comparable sense of liberation in Franklin leads him to rape Mathinna. There is also an unmistakable echo of Freud, and at the same time of Conrad's Heart of Darkness, in the portrayal of a minor character, Edward Kerr, an agent of the Van Diemen's Land Company, who succumbs to the wilderness of the island. ${ }^{19}$ Franklin admires the man for bravely facing "the horror he has discovered in himself" and having the courage to act "beyond good and evil" (181). Franklin begins to see Kerr as his secret double; the governor of Tasmania's decision to go on another expedition is primarily motivated by his desire to experience a similar sense of freedom in the wilderness of the Arctic.

Posthumously, Franklin becomes Dickens's secret sharer ${ }^{20}$, but for the writer, in hindsight, the polar regions take on the reverse meaning. In Dickens's imagination, the ice which held the explorer captive functions as a metaphor for his own sense of imprisonment and the lack of passion in his life: "He kept seeing the cold whiteness of the Northwest Passage, and he kept feeling himself trapped in it with Sir John's corpse" (73). The writer's tortuous oscillation between a sense of duty and his vague "wanting" results in somewhat contradictory actions: he evades the commission to write about "Englishmen meeting their ends nobly rather than as savages" (78), but becomes feverishly devoted to the task of putting on Wilkie Collins's play on the subject.

Dickens's commitment to the production of The Frozen Deep (he also made some additions to Collins's text [cf. Tomalin 277-278]; Ackroyd states that the play was in fact written at Dickens's direction [762]) was his other, indirect mode of refuting the suspicions of the English mariners' less than noble conduct. The action takes place during an Arctic expedition, but its focus is on the rivalry between two officers who happen to be in love with the same woman, and ends with the jilted lover suppressing his murderous impulses and even saving his rival's life, at the cost of his own happiness. Although the play is entirely fictional, it is related to the story of the actual expedition by projecting a view of heroism, endurance and extreme selfsacrifice which precludes the likelihood of descent into savagery. The play was very successful with the public (Tomalin 279); it grew from an amateur to a quasi-professional production, as several professional actors were taken on. Dickens, however, continued to play the central part of Wardour, the self-sacrificial hero. According to contemporary accounts, there was "frenzy" and "savage energy" in his performance (Ackroyd 773-775).

The message of The Frozen Deep is simple: when put to the test, away from 
"inhabited and civilised regions of the earth" (Collins 33), Englishmen will exercise heroic restraint. The play implicitly alludes to and simultaneously rejects the shocking possibility of prolonging one's existence by "the dreadful expedient", as Dickens put it in in his essay, by including a scene in which the main character, one of the stranded explorers, displays admirable self-control in the gratification of his appetite, despite being nearly mad with starvation and looking like "a wild animal" (Collins 107). When offered food by his rescuers, he sets aside a portion for his starving companion before "voraciously" "devour[ing]" his half (107). The closing words of the play reiterate its message: "He has won the greatest of all conquests - the conquest of himself" (116).

In the novel, Collins's sense of "growing irony" (86) when he utters those momentous words over the body of Wardour/Dickens while enacting the part of Wardour's antagonist, stems from his awareness of the discrepancy between Dickens's adopted stage persona and the imperfections in his private life. For Dickens, keeping passions under control is not only "what mark[s] the English out as different from savages", but is also his private life's project: "only such severe disciplining of his heart allowed him his success, prevented him from falling into the abyss like his debtor father, like his wastrel brothers; from becoming, finally, the savage he feared himself to be" (43-44). His success in portraying Wardour ${ }^{21}$, fostered by his struggle to imitate the character's noble and selfless behaviour, is clearly related to his effort at self-control. It is therefore ironic that a play about disciplining one's heart brings together Dickens and his future mistress. ${ }^{22}$ It is at the time of his greatest theatrical triumph, when he enacts before a mesmerized audience the death of Wardour in the arms of the actress Ellen Ternan, that Dickens finally relaxes his selfdiscipline - he already knows they will have an affair: "And he, a man who had spent a life believing that giving in to desire was the mark of a savage, realised he could no longer deny wanting" (241). This is a moment of liberation and excitement, but also a moment of personal integrity and courage, when he stops denying and suppressing his impulses. But there is also dramatic irony in the fact that the Victorian audience do not realize they are in fact watching both a man and his mask (to use Yeats's formulation), and a double act: public conformity with social norms and private transgression.

Dickens envisions this moment in terms of the metaphor of leaving an icebound land for a green valley (246-247). This does not mean, however, that the novel ends on a note of uncritical endorsement of freedom from discipline. After all, Dickens already anticipates that his new life of passion will bring him both joy and pain. Earlier, the writer expressed the view that it is passions 
that enslave a man (30) - he never renounces this assertion. What further complicates the ambiguous description of this turning point in the writer's life is the next (and last) chapter which recounts Mathinna's miserable end, eloquent of civilization's failures. Hence, the novel lends itself to contradictory readings; Ron Charles in The Washington Post claims that "Flanagan charts the wreckage done by people convinced that repressing their desires - and others' is the key to civilization", whereas Mark Rubbo interprets Wanting as a novel about "unbridled desire and its tragic consequences". Indeed, justification for both readings may be found in the novel. The ideological framework of Wanting converges with stereotypical representations of the Victorians in contemporary fiction insofar as the book critiques Victorian repression and challenges the nineteenth-century imperialist civilizing project. Where Flanagan departs from the convention is a refusal to reverse the Victorian hierarchy of social norms and freedom from restrictions. In the portrayal of Dickens, Franklin and Lady Jane Franklin the strict opposition which the characters continue to verbalize as "civilization" against "savagery" in fact may be conceptualized more adequately as the tension between restraint and freedom, or between repression and transgression - and the novel shows uses and misuses of both. In Heart of Darkness, Marlow states that Kurtz's degeneration happened due to his lack of restraint: "there was nothing exactly profitable in these heads being there [at Kurtz's station]. They only showed that Mr Kurtz lacked restraint in the gratification of his various lusts, that there was something wanting in him" (83). What is certainly wanting in the Victorian characters in Flanagan's novel is the ability to find an equilibrium between private passions and public norms, which they wrongly set against each other in an effort to uphold normative definitions of civilization and savagery.

\section{Notes}

1. The novel won the Queensland Premier's Prize, the Western Australian Premier's Prize and the Tasmania Book Prize.

2. The English-born Robinson spent the years 1824-1852 in the Australian colonies. In his role as "Protector of Aboriginals" he tried to save as well as to civilize and Christianize the remaining indigenous people of Tasmania. His methods, however (e.g., forcing them to resettle in a reservation), proved to be very detrimental. From the contemporary perspective, the model of benevolent colonialism he represented is subject to predominantly negative assessment. Robinson kept journals which are an important source on that period in Tasmanian history (cf. Brantlinger 48-49, 53). 


\section{BOŻENA KUCAŁA}

Robinson also appears as a character in Gould's Book of Fish (2001), another novel by Richard Flanagan concerned with the history of Tasmania.

3. Likewise, Ackroyd concludes that the writer's relations with Ellen are shrouded in obscurity (1023-1024). In his biography of Dickens, Michael Slater asserts that although the exact nature of the writer's relations with Ellen cannot be ascertained (Dickens and Women 139), the impact of this relationship may be seen in Dickens's preoccupation with the question of guilt and a double life in his later fiction (213).

4. The story of Franklin's last expedition has inspired a number of novels, e.g. Robert Edric's The Broken Lands: A Novel of Artic Disaster (1992) and Dan Simmons's The Terror (2007).

5. The Tasmanian-born Richard Flanagan had earlier published another historical novel set in Tasmania at the time of British colonization. Gould's Book of Fish (2001) tells the story of a convict settling in Van Diemen's Land in the early $19^{\text {th }}$ century. Flashbacks from the history of the land appear also in the visions of a dying man in Flanagan's debut novel, Death of a River Guide (1994). The river in question is the Franklin, named after Sir John Franklin. Flanagan has also written a non-fiction book on Tasmanian history, A Terrible Beauty: History of the Gordon River Country (1985).

6. Proof of cannibalism was found in 1859 by another explorer, William Hobson. He came across the remains of two officers from Franklin's expedition, one of whom had apparently eaten his companion (Dalton 126). Search for the lost expedition continued in the $20^{\text {th }}$ century and gradually more artefacts were discovered. In 1993 a team of researchers found more skeletons, with indisputable signs of cannibalistic practices, and thereby Rae's report was conclusively corroborated (Dalton 130).

7. This part of Dickens's letter is quoted verbatim in the novel, when Dickens reveals to Wilkie Collins his intention to take up Lady Jane's commission (38).

8. Dickens's twenty-first century descendant Gerald Dickens made a public apology to the Inuit (McCoogan 6).

9. For example, the narrator advises that 1839, when Robinson was involved in his aboriginal-saving mission, was also the year when the first photograph was taken, a jihad against the French was declared and Charles Dickens was becoming famous following the publication of Oliver Troist (3).

10. In a knowing tone, the narrator summarizes a cliché about the Victorians: "Family, of course, was everything by that morning of 1854 ... Everybody had to be family and all had to celebrate family" (32).

11. E.g., "[Wilkie Collins] was yet to invent the detective novel, to be celebrated by his age as one of the great novelists and thereafter forgotten" (38).

12. In his fournals, Robinson referred to the aboriginal Tasmanians as his "sable friends" (Brantlinger 48).

13. The historical facts are at least as gruesome as the details in the novel. The College of Surgeons in London kept a collection of Tasmanian skulls. The body of William Lanney, known as King Billy, the last Tasmanian aboriginal man, was coveted by the Royal Society, but in its entirety. Therefore, Dr W.L. Crowther, anxious to carry out his own measurements, decapitated the body and inserted another skull. The body underwent further dismemberment and dislocation; the fate of the head remains unknown, although it is thought to be at the College of Surgeons in London (Brantlinger $5^{8-59}$ ).

14. As Dickens had done earlier in his article, Tylor dismisses the concept of the noble savage, 
insisting on the savages' innate bestiality. His examples include the Esquimeaux: "Our Polar explorers may well speak in kindly terms of the industry, the honesty, the cheerful considerate politeness of the Esquimeaux; but it must be remembered that these rude people are on their best behaviour with foreigners, and that their character is apt to be foul and brutal where they have nothing to expect or fear" (30).

15. In the novel, Lady Jane alludes to these facts but refuses to treat them as evidence that men like her husband and his crew could sink as low as cannibalism; the convicts, in her opinion, "were men devoid of religion, a hundred times worse than the most barbarous heathens because they had turned away" (29-30).

16. Tammy Lai-Ming Ho cites several episodes in the novel in which the Franklins' perception of Mathinna is coloured by references to eating (17-18). Following the colonization of Tasmania, the aboriginal population began to dwindle rapidly. It is estimated that the Tasmanians had been obliterated by 1876 . The speed of this process attracted the attention of Darwin, who discussed it as a case study of why certain primitive races were becoming extinct when confronted with civilization (cf. Brantlinger 48-49).

17. Victorian sexual taboos were the focus of John Fowles's The French Lieutenant's Woman (1969), a pioneer neo-Victorian novel.

18. Here is how the episode is described in the novel: "That night the universe had flowed into him, he was open to everything, he was alive to other humans and to himself in a way he had never known" (6o).

19. Kerr boasts of having the heads of native people on the ridge of his hut - possibly an echo of the description of Kurtz's dwelling in Conrad's story. In Heart of Darkness, Conrad also questions the "civilization" vs "savagery" opposition by having Marlow claim that in extreme circumstances anyone may lapse into cannibalism: "No fear can stand up to hunger, no patience can wear it out, disgust simply does not exist where hunger is" (6o). Therefore, having a group of hungry cannibals on board his steamer, Marlow wonders at their "restraint". Conrad's narrator is familiar with the story of John Franklin - he mentions him and his two lost ships before embarking on his own tale (7).

20. Dickens's biographies recount his confession to Wilkie Collins that he wanted to "escape from [himself]" and go on an expedition to faraway places (Slater, Dickens and Women 204).

21. Reviewers agreed that Dickens was the star of the show, equalling the skills of professional actors (Tomalin 279).

22. In the novel, the speculations connected with the role of Ellen Ternan in Dickens's life become a matter of fact. In a résumé, the narrator states that they will have a thirteenyear long affair, and will have a child together (241).

\section{Works Cited}

Ackroyd, Peter. Dickens. London: Sinclair-Stevenson, 1990. Print.

Boyd, William. "Saints and Savages." The New York Times. 24 June 2009. Web. Accessed 15 June 2018.

Brantlinger, Patrick. Taming Cannibals: Race and the Victorians. Ithaca: Cornell University Press, 2011. Print. 
Bridgham, Elizabeth. "Richard Flanagan, Wanting." Dickens Quarterly. vol. 28. no. 2. 2011: 159-162. Academic Search Complete.

Charles, Ron. "'Wanting,' by Richard Flanagan." The Washington Post. 27 May 2009. Web. Accessed 15 June 2018.

Collins, Wilkie. The Frozen Deep. Bielefeld und Leipzig: Velhagen \& Klasing, 1936. Print.

Conrad, Joseph. Heart of Darkness. London: Penguin, 1994 [1899]. Print.

Dalton, Anthony. Sir Fohn Franklin: Expeditions to Destiny. Surrey, B.C.: Heritage House, 2012. eBook Academic Collection (EBSCOhost).

Dickens, Charles. "The Lost Arctic Voyagers" [part I]. Household Words. 2 December 1854: 361-365. Web. Accessed 11 June 2019.

--.. "The Lost Arctic Voyagers" [part II]. Household Words. 9 December 1854: 385-393. Web. Accessed 11 June 2019.

---. Great Expectations. London: Penguin, 1985 [1861]. Print.

Flanagan, Richard. Wanting. London: Vintage, 2016 [2008]. Print.

Foden, Giles. "Wanting by Richard Flanagan." The Guardian. 26 September 2009. Web. Accessed 16 June 2018.

Forster, John. The Life of Charles Dickens. Vol. 2. London: J.M. Dent \& Sons; New York: E.P. Dutton \& Co., 1927. Print.

Freud, Sigmund. Civilization and Its Discontents. Trans. and ed. James Strachey. New York: Norton, 1962. Print.

Grossman, Lev. "What the Dickens." Time. 1 June 2009: 6o. Academic Search Complete.

Heilmann, Ann and Mark Llewellyn. "Introduction. Neo-Victorianism and Post-Authenticity: On the Ethics and Aesthetics of Appropriation." NeoVictorianism: The Victorians in the Twenty-First Century, 1999-2009. Basingstoke: Palgrave Macmillan, 2010. 1-27. Print.

Ho Lai-Ming, Tammy. "Cannibalised Girlhood in Richard Flanagan's Wanting." Journal of Neo-Victorian Studies. vol. 5. no. 1. 2012: 14-37. Web. Accessed 6 January 2019.

Humpherys, Ann. "The Afterlife of the Victorian Novel: Novels about Novels." A Companion to the Victorian Novel. Eds. Patrick Brantlinger and William B. Thesing. Malden, MA; Oxford: Blackwell, 2002. 442-457. Print.

Joyce, Simon. "The Victorians in the Rearview Mirror." Functions of Victorian Culture at the Present Time. Ed. Christine L. Krueger. Athens, Ohio: Ohio University Press, 2002. 3-17. Print.

Kakutani, Michiko. "In the Wilds of Tasmania, the Impacts of Empire." The New York Times. 21 May 2009. Web. Accessed 13 June 2018. 
McCoogan, Ken. "Introduction." John Rae. The Arctic Journals of Fohn Rae. Toronto: Touchwood Editions. 2012. 1-7. eBook Academic Collection (EBSCOhost).

McGowan, John. "Modernity and Culture, the Victorians and Cultural Studies."

Victorian Afterlife: Postmodern Culture Rewrites the Nineteenth Century. Eds.

Dianne F. Sadoff and John Kucich. Minneapolis and London: University of Minnesota Press, 2000. 3-28. Print.

Raabus, Carol. "The Hidden Story of Mathinna: Spirited, Gifted, Utterly Destroyed.” ABC Radio Hobart 16 February 2011. Web. Accessed 1 June 2018.

Rae, John. The Arctic Fournals of John Rae. Toronto: Touchwood Editions, 2012. eBook Academic Collection (EBSCOhost).

Rubbo, Mark. "Wanting: Richard Flanagan." Readings. 30 October 2008. Readings website. Web. Accessed 2 June 2018.

Slater, Michael. Dickens and Women. London and Melbourne: J.M. Dent \& Sons, 1986. Print.

---. Dickens' Journalism Volume III: 'Gone Astray' and Other Papers from Household Words, 1851-1859. J. M. Dent/Orion Publishing Group, 1998. Reproduced in DfO: Dickens fournals Online. Web. Accessed 3o May 2018.

Smiley, Jane. Charles Dickens. London: Weidenfeld \& Nicolson, 2002. Print. Tomalin, Claire. Charles Dickens: A Life. New York: Penguin, 2011. Print.

Tylor, Edward Burnett. Primitive Culture. Researches into the Development of Mythology, Philosophy, Religion, Art, and Custom. Vol. 1. London: John Murray, 1920 [1871]. Print.

BOŻENA KUCAŁA is Assistant Professor at the Institute of English Studies, Jagiellonian University in Kraków, where she teaches nineteenth-century and contemporary English literature. Her research interests include contemporary fiction, especially the historical novel and neo-Victorian fiction. Main publications: Intertextual Dialogue with the Victorian Past in the Contemporary Novel (2012), co-edited books: Writer and Time: Fames foyce and After (2010), Confronting the Burden of History: Literary Representations of the Past (2012), Travelling Texts: F.M. Coetzee and Other Writers (2014). She has also published numerous articles on contemporary British and Irish writers (Graham Swift, A.S. Byatt, John Banville).

bozena.kucala@uj.edu.pl 